\title{
BIOSYNTHESIS OF STEROIDS BY GRANULOSA CELLS OF THE PORCINE OVARY IN VITRO
}

\author{
LARS BJERSING* AND HANS CARSTENSEN† \\ * Institute of Pathology, University of Umea, Umea 6, and \\ $\dagger$ Laboratory for Research on Hormones of Reproduction, University Hospital, \\ University of Uppsala, Uppsala, Sweden
}

(Received 23rd May 1966, revised 10th October 1966)

\begin{abstract}
Summary. Incubation of granulosa cell aggregates from porcine ovarian follicles with progesterone-4- ${ }^{14} \mathrm{C}, 17 \alpha$-hydroxyprogesterone-4${ }^{14} \mathrm{C}$, pregnenolone-7 $\alpha_{-}{ }^{3} \mathrm{H}$, testosterone-4- ${ }^{14} \mathrm{C}$ and androstene-3,17dione-4- ${ }^{14} \mathrm{C}$ showed that they contained efficient $3 \beta$-hydroxysteroid dehydrogenase, $20 \alpha$-hydroxysteroid dehydrogenase and $17 \beta$-hydroxysteroid dehydrogenase enzyme activities. There were also some aromatizing and probably some 21-hydroxylating enzyme activities. The granulosa cells were particularly low in $17 \alpha$-hydroxylase and sidechain cleaving enzyme activities although some activity was demonstrated.
\end{abstract}

\section{INTRODUCTION}

From studies on rat ovarian micro-transplants Falck (1959) concluded that both granulosa and theca cells were needed to obtain oestrogen formation. Since then a number of biochemical studies concerning steroid hormone production by individual ovarian cell types have been published (Bjersing \& Carstensen, 1964; Ryan \& Short, 1965, 1966; Channing 1966; Ryan \& Petro, 1966). The present work is an extension of our earlier report.

Isolation of cells

\section{MATERIALS AND METHODS}

Fresh ovaries were obtained at the slaughter-house from sexually immature sows with body weights of about $100 \mathrm{~kg}$. The ovaries lacked corpora lutea and weighed 2.0 to $4.5 \mathrm{~g}$. In specified cases ovaries from adult sows with body weights of about $200 \mathrm{~kg}$ were used, the ovaries weighing 5.9 to $34 \mathrm{~g}$. The granulosa cells were prepared from follicles with a mean diameter of about $4 \mathrm{~mm}$. They were separated from the thecal layers and collected as described by Bjersing (1962). During the collection the cell aggregates were suspended in isotonic Krebs-Ringer bicarbonate buffer, usually at $\mathrm{pH} 7 \cdot 3$, with glucose $(200 \mathrm{mg} / 100 \mathrm{ml})$. After centrifugation for $5 \mathrm{~min}$ at about $3000 \mathrm{rev} / \mathrm{min}$ the medium was decanted and drained before determining the wet weight of the 
cells. They were then suspended in buffer-glucose solution and aliquots transferred with a silicone-coated pipette into 50-ml flasks and the final volume adjusted to $5 \mathrm{ml}$. Some experiments with other tissues and cells were also done (see Table 1).

\section{Incubation}

Incubations were started within $3 \mathrm{hr}$ after slaughter and were carried out for 3 to $4 \mathrm{hr}$ at $37.5^{\circ} \mathrm{C}$, shaking in an atmosphere of $6.5 \% \mathrm{CO}_{2}$ in $\mathrm{O}_{2}$. Purified labelled steroid dissolved in $0.1 \mathrm{ml}$ of propylene glycol was added, and in some experiments co-factors were added as follows: sodium fumarate and nicotinamide, $200 \mu$ moles; adenosine-3',5'-monophosphate, $3 \mu$ moles; AMP 17.5, $\mu$ moles; ATP, $20 \mu$ moles; NAD, $4 \mu$ moles; NADP, $8.5 \mu$ moles; NADPH, $27.5 \mu$ moles; glucose-6-phosphate (G6P), $11 \mu$ moles; and 65 to 110 Kornberg units of glucose-6-phosphate-dehydrogenase (G6PD).

\section{Extraction and chromatography of steroids}

After incubation the contents of each flask were homogenized in a PotterElvehjem homogenizer and extracted in a separating funnel with methylene chloride $(3 \times 3$ volumes $)$ which had been purified with sodium carbonate and redistilled over calcium chloride. The extracts were evaporated by rotary evaporation and an aliquot $(0.5$ to $1.0 \%)$ was taken for radio-activity counting. The extract was partitioned in the solvent systems, hexane-water and hexane$70 \%$ aqueous ethanol (Carstensen, 1961); the hexane phase of the first partition was subjected to the second partition and the water and ethanol-water phases of both partitions were extracted with methylene chloride. The purpose of these partitions was to isolate fat in the final hexane fraction, which was discarded after counting its radio-activity, and also to make a group separation of the steroids according to their polarity. The solvent partition procedure was omitted in Exps. 4, 10 and 11. Paper chromatography (PC) was carried out in Bush-type systems on Whatman No. 1 chromatography paper (Bush, 1952) and by reversed phase partition chromatography on purified, fully-acetylated Schleicher and Schull chromatography paper No. 2043-A/42-ac (Carstensen 1960). The Bush-type systems were used at room temperature and were prepared as follows: PC-1, n-hexane 450, benzene 50, methanol 425, water 75 ; PC-2, n-hexane 33, benzene 17, methanol 40, water 10; PC-3, n-hexane 20, benzene 30 , methanol 40 , water 10 ; PG-4, toluene 50 , methanol 30 , water 20 . The system used for reversed phase chromatography (BEW-40) was: n-butyl acetate 50 , ethanol 20, water 30 .

Standard steroids were run on parallel strips and located by their absorption of ultraviolet light (lamp emitting at about $256 \mathrm{~m} \mu$ ) or by colour reactions; isotopically-labelled substances were located by scanning in a FriesekeHoepfner gas flow counter (Model 452) with or without an end window. Elution from Whatman No. 1 paper was carried out with $15 \mathrm{ml}$ of methanol and from acetylated filter paper with $15 \mathrm{ml}$ of diethyl ether-acetone $(1: 1, \mathrm{v} / \mathrm{v})$. $R_{\mathrm{M}}$ and $\Delta R_{\mathrm{M}}$ values were calculated according to Bush (1961). Thin layer chromatography (TLC) was performed with Desaga equipment using silica gel G (Waldi, 1962). Detection of standard steroids without heating was 
performed as described by Carstensen (1966). The chromatoplates were scanned using a Frieseke-Hoepfner gas flow detector (Model 407) with an end window. Elution of steroids from the silica gel was carried out with either absolute ethanol or diethyl ether-acetone $(1: 1)$.

\section{Preparation of derivatives}

Methylation of oestrogens was carried out by dissolving fractions containing oestrone and oestradiol- $17 \beta$ in $8 \mathrm{ml}$ of benzene and extracting twice with $1 \mathrm{vol}$. of $1.6 \%$ sodium hydroxide solution; this was then neutralized with $1.2 \mathrm{~g}$ of boric acid to $\mathrm{pH} 10.5$ to 11.0 , and either extracted ('phenolic fraction') or, as a rule, methylated according to Brown (1955). Acetylation of primary and secondary hydroxyl groups was carried out with acetic anhydride in pyridine by the method described by Dominguez, Seely \& Gorski (1963), and acetylation of tertiary hydroxyl groups by Turner's method described by Roberts \& Warren (1964). Reduction with sodium borohydride was carried out according to the method of Marrian, Loke, Watson \& Panattoni (1957) except that acidification was omitted and extraction was performed with methylene chloride. For the oxidation of steroids with chromic acid, two procedures were used. Testosterone was oxidized according to Bush (1961). This method failed to oxidize 20hydroxyl groups which were oxidized as follows. The steroid was dissolved in $0.1 \mathrm{ml}$ of glacial acetic acid containing $0.5 \%(\mathrm{w} / \mathrm{v})$ chromic trioxide. The tube was then stoppered and left in the dark for $15 \mathrm{~min}$. After the addition of $1 \mathrm{ml}$ of ethanol-water $(1: 5, \mathrm{v} / \mathrm{v})$, the steroid was extracted with $10 \mathrm{ml}$ of methylene chloride by vigorous shaking for $10 \mathrm{sec}$. The methylene chloride was finally washed with $1 \mathrm{ml}$ of distilled water and evaporated. Oxidation with periodic acid was by the procedure of Zaffaroni \& Burton (1951). Oxidation with pure $3 \beta, 17 \beta$-hydroxysteroid dehydrogenase was performed essentially as described by Marcus \& Talalay (1956). The pure enzyme was prepared according to Delin \& Porath (1963). Reduction with 20ß-hydroxysteroid dehydrogenase was done according to the technique of Hübener \& Sahrholz (1959) with crystalline enzyme (Boehringer, Mannheim).

\section{Measurement of radio-activity}

Eluates were applied to alumina planchettes and dried and the radioactivity in the infinitely thin samples was measured in an automatic gas flow counter (Frieseke-Hoepfner Model 411) with a windowless detector (Model 407). The efficiency of counting was $21 \%$ for ${ }^{3} \mathrm{H}$ and $57 \%$ for ${ }^{14} \mathrm{C}$, and the counting error was less than $5 \%$ at a fiducial limit of $95 \%$. In the crystallization procedures ${ }^{3} \mathrm{H}$ and ${ }^{14} \mathrm{C}$ were measured simultaneously in a twochannel Packard Tri-Carb scintillation spectrometer.

\section{Calculation of results}

The results were calculated as the relative conversion of substrate into the final steroid fractions. It was not possible to correct for total losses during the procedure but recoveries were continuously checked throughout to assess that major losses did not occur. 


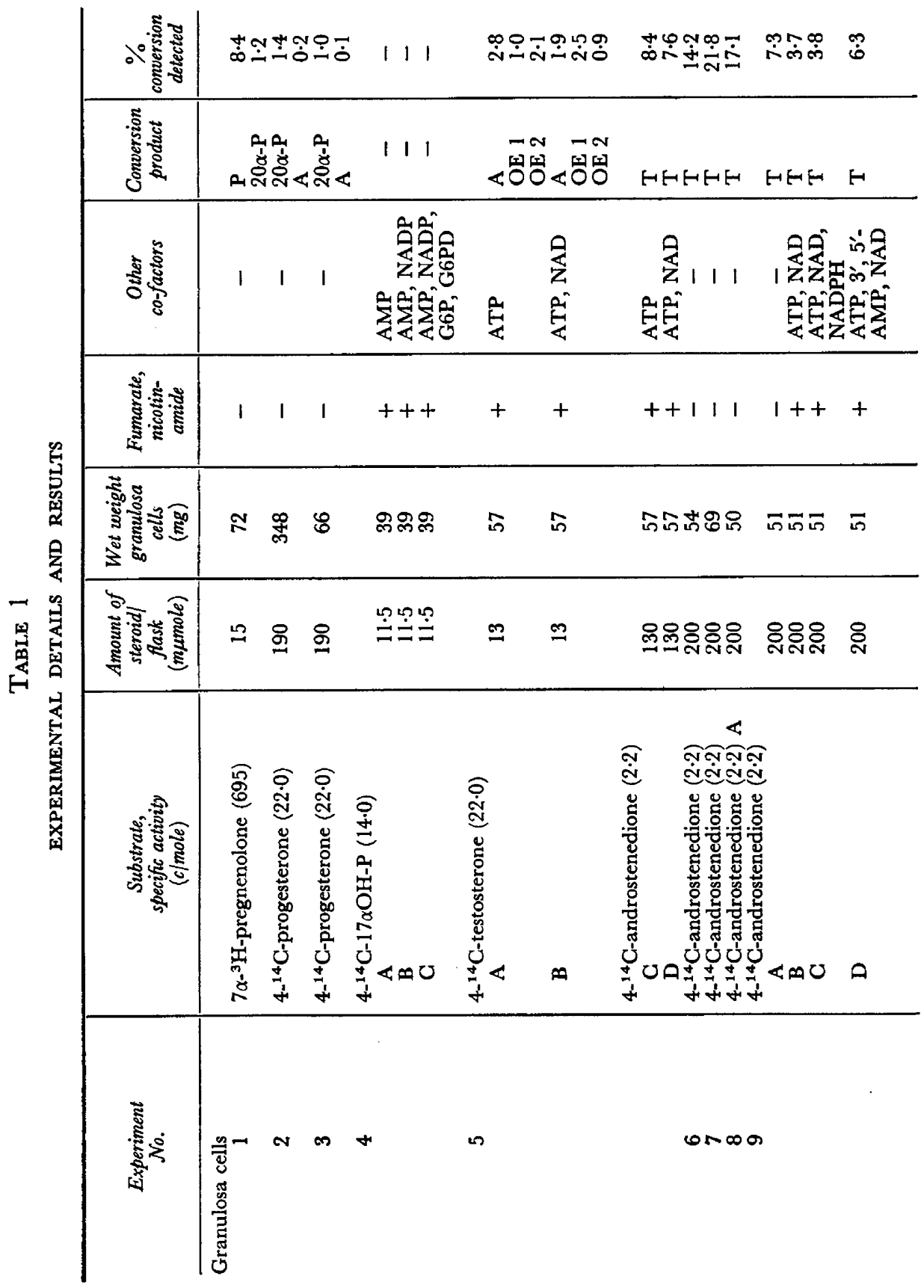




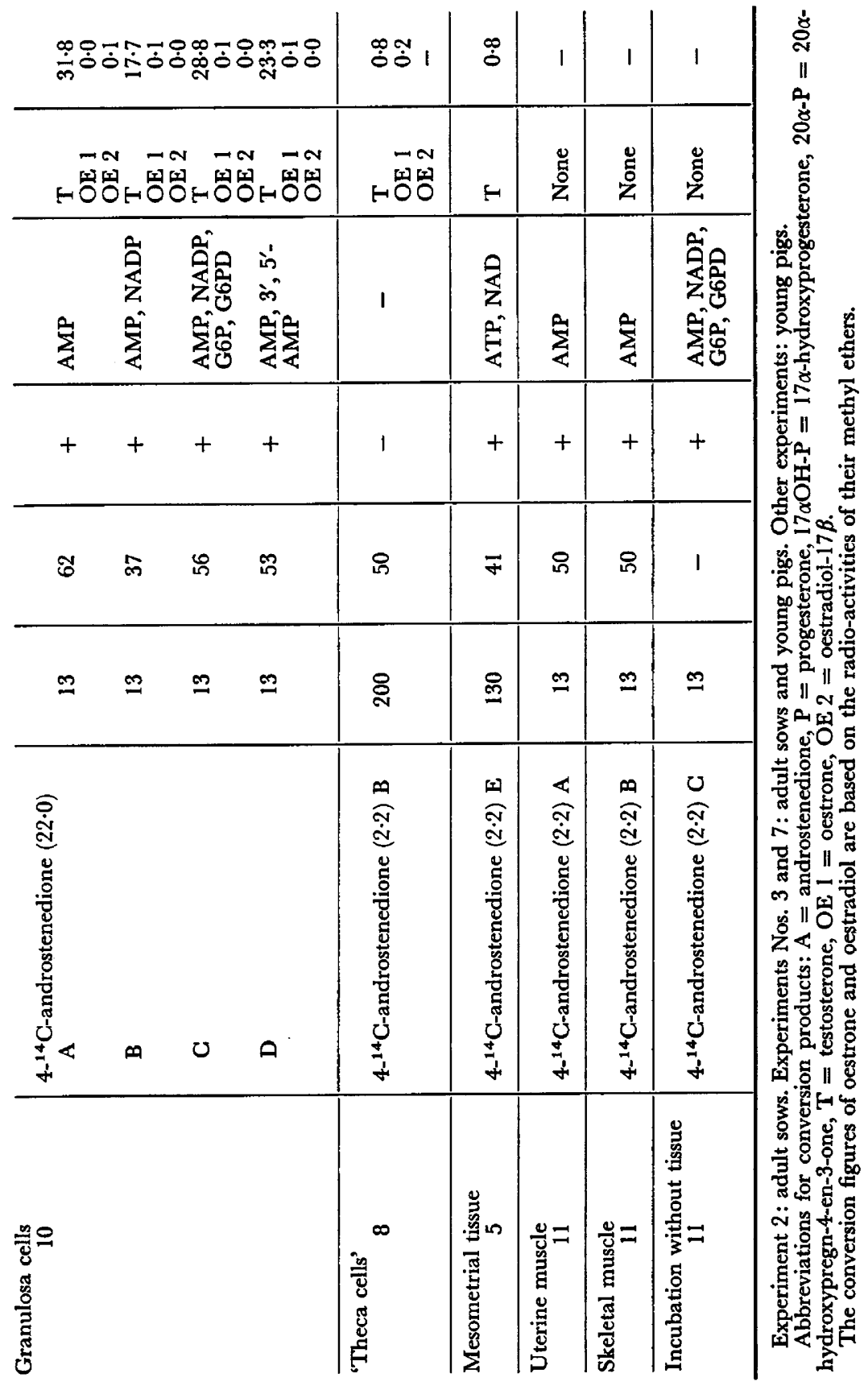




\section{RESULTS}

The total recovery determined after solvent partition or after the first chromatogram varied between 79 and $100 \%$ with two exceptions $66 \%$ in Exp. $4 \mathrm{~A}$ and $40 \%$ in Exp. 1).

The elution recoveries for the three types of chromatography used were checked for testosterone-4- ${ }^{14} \mathrm{C}$ and oestradiol- $17 \beta-4-{ }^{14} \mathrm{C}$ and was about $90 \%$ for amounts of $100 \mathrm{ng}$ to $50 \mu \mathrm{g}$ except for oestradiol-17 $\beta-{ }^{14} \mathrm{C}$ after TLC when only 30 to $40 \%$ of nanogram amounts were recovered.

The main conversion products from the different incubation experiments are shown in Table 1. Only steroids whose identity has been reasonably well established by their chromatographic mobility, derivative formation and, in some instances, crystallization to constant specific activity have been included. When other major components were isolated they are mentioned below.

\section{TABLE 2}

TRITIUM: GARBON RATIOS OF CRYSTALS DURING RECRYSTALLIZATION WITH THE AUTHENTIC COMPOUND USING THE DUALLABEL METHOD

\begin{tabular}{|c|c|c|c|}
\hline $\begin{array}{l}\text { Exp. } \\
\text { No. }\end{array}$ & Compound & $\begin{array}{c}\text { Crystallization } \\
\text { No. }\end{array}$ & $\begin{array}{c}\text { Tritium-carbon } \\
\text { ratio }\end{array}$ \\
\hline 1 & Progesterone & $\begin{array}{l}1 \\
2 \\
3\end{array}$ & $\begin{array}{l}0.70 \\
0.76 \\
0.76\end{array}$ \\
\hline 1 & $20 \alpha$-Hydroxypregn-4-en-3-one & $\begin{array}{l}1 \\
2 \\
3\end{array}$ & $\begin{array}{l}0.30 \\
0.23 \\
0.24\end{array}$ \\
\hline 2 & $20 \alpha$-Hydroxypregn-4-en-3-one & $\begin{array}{l}1 \\
2 \\
3\end{array}$ & $\begin{array}{l}0.78 \\
0.84 \\
0.87\end{array}$ \\
\hline 3 & Androstenedione & $\begin{array}{l}1 \\
2 \\
3 \\
4\end{array}$ & $\begin{array}{l}0.53 \\
0.65 \\
0.61 \\
0.55\end{array}$ \\
\hline
\end{tabular}

Solvents: Crystallization No. 1, methanol+water; crystallization No. 2, ethyl acetate +hexane; crystallization No. 3, acetone + water; crystallization No. 4 , acetone + water.

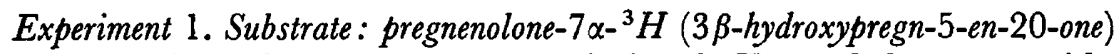

A number of components were isolated. Two of these were identified as progesterone and $20 \alpha$-hydroxypregn-4-en-3-one.

Progesterone. A major product was formed with a yield of $8.4 \%$ and had the same chromatographic mobility as progesterone (PG-1 and PG-2) and did not acetylate. After the addition of carrier progesterone $(30 \mathrm{mg})$ and progesterone$4-{ }^{14} \mathrm{C}$ the steroid was recrystallized three times from various solvents and the tritium-carbon ratios of the crystals were determined (Table 2).

$20 \alpha$-Hydroxypregn-4-en-3-one. In the original PG-2 there was a peak with approximately the same $R_{F}$ as $20 \alpha$-hydroxypregn-4-en-3-one or dehydroepi- 
androsterone. Most of this material was acetylated with a change in $R_{\mathrm{M}}$ of -0.88 which corresponded to that obtained in the acetylation of a $20 \alpha-$ hydroxyl group but differed from that of a $3 \beta$-hydroxyl. The acetate represented $1.2 \%$ of the substrate. After hydrolysis of the acetate, the compound was purified in PG-2, oxidized with chromic acid and rechromatographed in PC-2 where it was located as a single peak with the same $R_{F}$ as progesterone. Carrier progesterone $(30 \mathrm{mg})$ and progesterone $-4-{ }^{14} \mathrm{C}$ were added to the eluate and the steroid was recrystallized three times from different solvents. The tritium-carbon ratios of the crystals are shown in Table 2.

Other components. Tentative chromatographic evidence suggested the formation of a $3 \beta$-hydroxy-20,21-ketol or 21-hydroxypregnenolone. No evidence was obtained for the presence of $17 \alpha$-hydroxypregnenolone, $17 \alpha$-hydroxyprogesterone or androstenedione. No radio-active peak was found after acetylation and chromatography in PC-2 of the area corresponding to $3 \beta$ acetoxyandrost-5-en-17-one. However, after elution of this area the radioactivity of the fraction amounted to $0.3 \%$ of that of the precursor. The presence of a small amount of dehydroepiandrosterone could therefore not be excluded.

\section{Experiments 2-3. Substrate: progesterone-4- ${ }^{14} C$}

20 $\alpha$-Hydroxypregn-4-en-3-one. After chromatography in PC-2, BEW-40 and the TLC system, ethyl acetate-cyclohexane $1: 1$, a major product with the same $R_{F}$ values as $20 \alpha$-hydroxypregn-4-en-3-one was obtained in a yield of 1.4 and $1.0 \%$ in Exps. 2 and 3 respectively. The compound was oxidized with chromic acid after which it had the same $R_{F}$ as progesterone in PG-1. When part of the original component was acetylated and chromatographed in PC-1 a change in $R_{\mathrm{M}}$ equal to $-1 \cdot 12$ was observed, similar to that found when standard $20 \alpha$-hydroxypregn-4-en-3-one was acetylated $\left(\Delta R_{\mathrm{M}}=-1 \cdot 13\right)$. After hydrolysis of the acetate, the free steroid was purified by chromatography, oxidized and crystallized (Exp. 2, Table 2) in the same way as described for $20 \alpha$-hydroxypregn-4-en-3-one in Exp. 1, except that progesterone- $7 \alpha-{ }^{3} \mathrm{H}$ was added instead of progesterone- $4-{ }^{14} \mathrm{C}$.

Androstenedione. In Exp. 2, $60 \mu \mathrm{g}$ of carrier androstenedione were added after chromatography in PC-2. On chromatography in PC-1 both UV absorbancy and radio-activity were recorded stepwise along the strip. The major radioactive peak coincided with the ultraviolet absorbancy maximum of the carrier at $246 \mathrm{~m} \mu$. This peak was eluted and re-chromatographed in the BEW-40 system where a radio-active component with the same $R_{F}$ value as androstenedione was obtained in a yield of $0.2 \%$. In Exp. 3, after chromatography in PC-2, the acetylation procedure did not alter the $R_{\mathrm{M}}$ in PC-1 where a peak with the mobility of androstenedione corresponded to $0.1 \%$ of the substrate. Androstenedione-1,2- ${ }^{3} \mathrm{H}$ and $30 \mathrm{mg}$ of authentic cold androstenedione were then added and the mixture recrystallized four times in different solvents (see Table 2).

Other components. Tentative chromatographic evidence also suggested the formation of $17 \alpha, 20 \alpha$-dihydroxypregn-4-en-3-one. No evidence was obtained for the presence of $17 \alpha$-hydroxyprogesterone or testosterone. 
Experiment 4. Substrate: $17 \alpha$-hydroxyprogesterone- $4-{ }^{14} C$

About $1 \%$ of the radio-activity of the substrate appeared as an unidentified component more polar than androstenedione in the chromatography system, PC-2. There was no evidence for the formation of androstenedione or testosterone. After repeated chromatography (PG-1, PG-2 and BEW-40) it was concluded that the remaining radio-activity consisted of unchanged precursor. Similar results were obtained in the three flasks incubated with or without NADP or a NADPH-generating system.

Experiment $5(A)$. Substrate: testosterone- $4-{ }^{14} C$

Androstenedione. A peak was obtained with the same $R_{F}$ values as androstenedione (PC-1, PC-2 and TLG). After elution and acetylation its $R_{F}$ remained the same. It corresponded to $2.8 \%$ of the substrate activity when incubated in the absence of NAD and $1.9 \%$ with NAD present.

Oestrone. After chromatography in PC-2 and after TLC, the area corresponding to oestrone represented $1.7 \%$ of the substrate when incubated without NAD and $3.4 \%$ with NAD. After methylation and TLC (ethyl acetate 35: cyclohexane 65), the corresponding values of eluted oestrone-3-methyl ether were $1.0 \%$ in incubations without NAD and $2.5 \%$ with NAD (Table 1 ).

Oestradiol-17 $\beta$. After chromatography as described for oestrone, $2.4 \%$ of the substrate activity was eluted from the oestradiol area in incubates without NAD and $1.0 \%$ with NAD. After $\mathrm{NaOH}$ extraction, methylation and TLC, $2.1 \%$ was obtained from incubations without NAD and $0.9 \%$ with NAD (Table 1 ).

Experiments $5(B)-10$. Substrate: androstenedione-4- ${ }^{14} C$

Testosterone. The major conversion product had the same $R_{F}$ as testosterone (PG-2) and absorbed ultra-violet light. After chromatography (12 hr in BEW$40)$ the product was eluted and acetylated. Its acetate had the same $R_{F}$ value in PC-1 as authentic testosterone acetate. The material isolated from granulosa cell incubates had an ultraviolet absorption maximum at $240 \mathrm{~m} \mu$ when it was dissolved in ethanol and measured in the Zeiss spectrophotometer.

In addition to the expected chromatographic behaviour in different systems, proof of structure was obtained by the following procedures: Oxidation with chromic acid or with pure $3 \beta, 17 \beta$-hydroxysteroid dehydrogenase yielded a product with the same mobility as androstenedione in PG-1; acetylation gave the expected $\Delta R_{\mathrm{M}}$ in $\mathrm{PC}-2\left(\Delta R_{\mathrm{M}}=-2 \cdot 1\right)$; reduction with sodium borohydride gave a polar derivative with the same mobility in $\mathrm{PG}-3$ as the reduction product of authentic testosterone; the product isolated in Exp. 10 after TLC gave the same fluorescence $\left(\lambda_{\max } 530 \mathrm{~m} \mu\right)$ as authentic testosterone in the fluorimetric assay of Korenman, Wilson \& Lipsett (1963).

When 'theca cell' tissue was incubated (Exp. 8B), the conversion of androstenedione into testosterone was 20 times less than when granulosa cells from the same ovaries were used (Exp. 8A).

Oestrogens. After repeated chromatography a small amount of radio-activity was recovered in the fractions corresponding to oestrone and oestradiol-17 $\beta$. Since this was somewhat higher in Exp. 8B (oestrone) and in Exp. 10 these fractions were further purified by $\mathrm{NaOH}$ extraction and methylation (Table 1). 
Experiment 11. Substrate: androstenedione-4- ${ }^{14} \mathrm{C}$

After incubation of finely-cut pig myometrium and skeletal muscle suspended in Krebs-Ringer bicarbonate buffer containing fumarate, nicotinamide and AMP, practically all radio-activity remained in the substrate steroid peak and no other peaks were observed when the PG-2 chromatogram was scanned at the highest sensitivity setting. When the substrate was incubated without tissue in the same medium with a NADPH generating co-factor system only the substrate peak was observed.

\section{DISCUSSION}

The results show that pig granulosa cells possess a variety of enzymes that transform steroid substrates. Evidence was obtained for the presence of $17 \beta$ hydroxysteroid dehydrogenase, $3 \beta$-hydroxysteroid dehydrogenase and $20 \alpha$ hydroxysteroid dehydrogenase. With testosterone as substrate, aromatization was indicated by the formation of oestrone and oestradiol- $17 \beta$ as shown by paper chromatography in different systems, thin layer chromatography, $\mathrm{NaOH}$ extraction, methylation and thin-layer chromatography of the methyl ethers. With androstenedione as substrate, the aromatization was less, but in most experiments some radio-activity definitely occurred in the oestrogen fractions after purification. Since the elution recoveries of the oestrogens were less with the low levels of the conversion products found in the present study, a substantial loss may have taken place particularly during the elution from thinlayer chromatograms of oestrogens and oestrogen methyl ethers.

The results also show that the granulosa cells under the present conditions have a low activity of enzymes involved in $17 \alpha$-hydroxylation and in side-chain cleavage. We reported earlier (Bjersing \& Carstensen, 1964) the absence of $17 \alpha-$ hydroxylating enzyme activity with pregnenolone as substrate. However, further work has disclosed some androstenedione formation in two experiments with progesterone as substrate (Exps. 2 and 3). The androstenedione was characterized both by carrier chromatography and crystallization.

The results agree well with the findings of Falck (1959) and provide direct experimental support for Short's (1962) hypothesis that granulosa cells have only a weak $17 \alpha$-hydroxylase activity and little or no 17 -desmolase activity. In a recent study on human granulosa and theca cells, Ryan \& Petro (1966) demonstrated effective conversion of pregnenolone and progesterone into $17 \alpha$ hydroxyprogesterone by both theca and granulosa cells after pretreatment with human menopausal gonadotrophin for 8 days. Another study on isolated equine granulosa cells reported the formation of oestrogens from testosterone (Ryan \& Short, 1965), which agrees well with our findings.

Since the conversion of androstenedione into testosterone was one of the most impressive effects in the present experiments, the $17 \beta$-hydroxysteroid dehydrogenase may play a key role in the hormone formation by the granulosa cells. The equilibrium of the enzyme reaction was highly in favour of testosterone at different co-factor conditions, substrate concentrations and at a physiological $\mathrm{pH}$. It is noteworthy that mesometrial tissue, at least in the vicinity of the gonad, had some capacity to transform androstenedione into testosterone while skeletal and uterine muscle did not. 
The occurrence or synthesis of the two 20-dihydroisomers of progesterone has mainly been demonstrated in corpora lutea and seems to be subject to some species variation (Velle, 1963; Ball \& Kadis, 1964; Savard, Marsh \& Rice, 1965). It is therefore of interest that $20 \alpha$-hydroxypregn-4-en-3-one was formed from progesterone and pregnenolone by isolated granulosa cells in the present study, regardless of whether the ovaries contained corpora lutea or not. The combined occurrence of $20 \alpha$-hydroxysteroid dehydrogenase and of a high $17 \beta$-hydroxysteroid dehydrogenase activity has further interest in view of the findings of Purdy, Halla \& Little (1964) that highly purified preparations of a soluble $17 \beta$-hydroxysteroid dehydrogenase from human placenta tissue possess low $20 \alpha$-hydroxysteroid dehydrogenase activity. Recently Davenport \& Mallette (1966) reported both $20 \alpha$ - and $17 \beta$-hydroxysteroid dehydrogenase activities in the soluble fraction of rabbit ovarian homogenate.

\section{ACKNOWLEDGMENTS}

This work was supported by grants from the Swedish Medical Research Council (Projects No. U 442, W 224, W 492 and 13X-78-01) and from the Department of Health, Education and Welfare (Project No. AM 06060) to one of us (H.G.).

The authors are indebted to Mrs Waldis Carstensen, Miss Ursula Mann and Miss Inger Johansson for skilful technical assistance. Dr O. V. Dominguez, Mexico City, Dr S. H. Eppstein of Upjohn Inc., Dr J. Fried of the Squibb Institute, New Brunswick, Professor W. Klyne, London, Dr R. Neher of the Ciba Inc., Basel, and Organon Ltd, Oss, through Pharmacia Inc., Uppsala, have most generously supplied us with standard steroids. All experiments were performed at the Laboratory for Research on Hormones of Reproduction, University of Uppsala, Uppsala, Sweden.

We are very indebted to Dr N. V. B. Marsden for his revision of the English text and for valuable suggestions.

\section{REFERENGES}

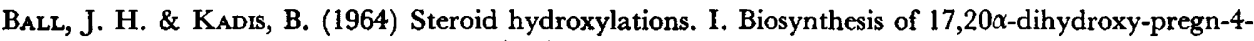
ene-3-one by sow ovary. Steroids, 4, 533.

BJERSING, L. (1962) Method for isolating pig granulosa cell aggregates in amounts allowing biochemical investigation of steroid hormone synthesis in vitro. Acta path. microbiol. scand. 55, 127.

Bjersing, L. \& Carstensen, H. (1964) The role of the granulosa cell in the biosynthesis of ovarian steroid hormones. Biochim. biophys. Acta, 86, 639.

BRown, J. B. (1955) A chemical method for the determination of oestriol, oestrone and oestradiol in human urine. Biochem. F. 60, 185.

BusH, I. E. (1952) Methods of paper chromatography of steroids applicable to the study of steroids in mammalian blood and tissues. Biochem. $\mathcal{7} .50,370$.

Bush, I. E. (1961) The chromatography of steroids, pp. 77 and 364. Pergamon Press, Oxford.

Carstensen, H. (1960) New solvent systems for the separation of corticosteroids by reversed phase chromatography on fully acetylated filter paper. Acta endocr., Copenh. 35, 1053, Suppl. 51.

Carstensen, H. (1961) Analysis of adrenal steroids in blood by counter-current distribution. Meth. biochem. Anal. 9, 127.

Carstensen, H. (1966) Chromogenic steroid reactions induced by silica in dilute sulfuric acid, useful for detection of steroids on thin-layer chromatoplates without heating, and a note on the specificity of the so-called Oertel, Allen \& Jensen reactions. European 7. Steroids, 1, 233.

Channing, C. P. (1966) Progesterone biosynthesis by equine granulosa cells growing in tissue culture. Nature, Lond. 210, 1266. 
Davenport, G. R. \& Mallette, L. E. (1966) Some biochemical properties of rabbit ovarian hydroxysteroid dehydrogenases. Endocrinology, 78, 672.

Delin, S. \& Porath, J. (1963) Purification of $\alpha$ - and $\beta$-hydroxysteroid dehydrogenases from $P$ seudomonas testosteroni by gel filtration. Biochim. biophys. Acta, 67, 197.

Dominguez, O. V., Seely, J. R. \& Gorski, J. (1963) Studies of the acetylation of steroids using 1carbon-14-acetic anhydride. Analyt. Chem. 35, 1243.

FALCK, B. (1959) Site of production of oestrogen in rat ovary as studied in micro-transplants. Acta physiol. scand. 47, Suppl. 163.

Hübener, H. J. \& Sahrholz, F. G. (1959) Über eine enzymatische Analyse von NebennierenrindenHormone im Blutplasma. Naturwissenschaften, 46, 112.

Korenman, S. G., Wilson, H. \& LipsetT, M. B. (1963) Testosterone production rates in normal adults. F. clin. Invest. 42, 1753.

Marcus, P. J. \& Talalay, P. (1956) Induction and purification of $\alpha$ - and $\beta$-hydroxysteroid dehydrogenases. 7. biol. Chem. 218, 661 .

Marrian, G. F., Loke, K. H., Watson, E. J. D. \& Panattoni, M. (1957) 16 $\alpha$-Hydroxyoestrone in the urine of pregnant women. Biochem. $\mathcal{J}$. 66, 60 .

Purdy, R. H., Halla, M. \& Littre, B. (1964) $20 \alpha$-Hydroxysteroid dehydrogenase activity a function of human placental 17 $\beta$-hydroxysteroid dehydrogenase. Biochim. biophys. Acta, 89, 557.

Roberts, J. D. \& Warren, J. C. (1964) Steroid biosynthesis in the fetal ovary. Endocrinology, 74, 846.

Ryan, K. J. \& Petro, Z. (1966) Steroid biosynthesis by human ovarian granulosa and thecal cells. F. clin. Endocr. Metab. 26, 46.

Ryan, K. J. \& ShORT, R. V. (1965) Formation of estradiol by granulosa and theca cells of the equine ovarian follicle. Endocrinology, 76, 108.

RyAN, K. J. \& SHORT, R. V. (1966) Cholesterol formation by granulosa and thecal cells of the equine follicle. Endocrinology, 78, 214.

Savard, K., Marsh, J. M. \& Rice, B. F. (1965) Gonadotropins and ovarian steroidogenesis. Recent Prog. Horm. Res. 21, 285.

SHORT, R. V. (1962) Steroids in the follicular fluid and the corpus luteum of the mare. A 'two cell type' theory of ovarian steroid synthesis. F. Endocr. 24, 59.

WALDI, D. (1962) Steroide. In: Dünnschicht-Chromatographie, Ein Laboratoriumshandbuch, p. 256. Ed. E. Stahl. Springer, Berlin.

VeLLe, W. (1963) Female gonadal hormones. In: Comparative Endocrinology, Vol. I, p. 111. Ed. U. S. von Euler and H. Heller. Academic Press, New York.

ZAFfaroni, A. \& BURTON, R. B. (1951) Identification of corticosteroids of beef adrenal extract by paper chromatography. F. biol. Chem. 193, 749. 